\title{
Quaternary alluvial fans of Ciudad Juárez, Chihuahua, northern México: OSL ages and implications for climatic history of the region
}

\author{
David Zúñiga de León ${ }^{1, *}$, Stephen Kershaw², Shannon Mahan ${ }^{3}$ \\ ${ }^{1}$ Instituto de Ingeniería y Tecnología, Universidad Autónoma de Ciudad Juárez, 32317 Ciudad Juárez, Chihuahua, México. \\ ${ }^{2}$ Institute for the Environment, Brunel University, Uxbridge, UB8 3PH, United Kingdom. \\ ${ }^{3}$ U.S. Geological Survey, Denver, Colorado, 80225, United States of America. \\ *dzuniga@uacj.mx
}

\begin{abstract}
Alluvial fans formed from sediments derived from erosion of the Juárez Mountains in northernmost México have a significant flood impact on the Ciudad Juárez, which is built on the fan system. The northern part of Ciudad Juárez is the most active; further south, older parts of the fan, upon which the rest of the city is built, were largely eroded by natural processes prior to human habitation and subsequently modified only recently by human construction. Three aeolian sand samples, collected from the uppermost (youngest) parts of the fan system in the city area, in places where human intervention has not disturbed the sediment, and constrain the latest dates of fan building. Depositional ages of the Quaternary alluvial fans were measured using Optically Stimulated Luminescence (OSL) on aeolian sands that have inter-fingered with alluvial fan material. These dates are: a) sample P1, $31 \mathrm{ka}$; b) sample P2, $41 \mathrm{ka}$; c) sample P3, 74 ka, between Oxygen Isotope Stages (OIS) 3 to 5. They demonstrate that fan development, in the area now occupied by the city, terminated in the Late Pleistocene, immediately after what we interpret to have been an extended period of erosion without further deposition, lasting from the Late Pleistocene to Holocene. The three dates broadly correspond to global glacial periods, implying that the cool, dry periods may reflect periods of aeolian transport in northern México in between phases that were wetter to form the alluvial fans. Alluvial fan margins inter-finger with fluvial terrace sediments derived from the Río Bravo, indicating an additional component of fan dissection by Río Bravo lateral erosion, presumed to be active during earlier times than our OSL ages, but these are not yet dated. Further dating is required to ascertain the controls on the fan and fluvial system.
\end{abstract}

Keywords: luminescence, northern México, Ciudad Juárez, alluvial fans.

\section{Resumen}

Los abanicos aluviales formados por sedimentos derivados de la erosión de las montañas de Ciudad Juárez en el norte de México, tienen un impacto significativo en las inundaciones de la ciudad que está desplantada sobre estos. La zona norte es la más activa y los abanicos más antiguos se localizan al sur donde la ciudad se desarrolló. Es decir, esta zona fue intensamente erosionada por procesos naturales antes de su reciente urbanización. Se recolectaron tres muestras de arena eólica en la parte más alta donde se localizan los abanicos recientes que aún no han sido alterados por la intervención humana, después se determinaron las edades mínimas de estas arenas eólicas que se intercalan con los abanicos Cuaternarios usando la técnica: Luminiscencia Óptica Estimulada (OSL por sus siglas en inglés): a) muestra P1, $31 \mathrm{ka}$; b) muestra P2, $41 \mathrm{ka}$; c) muestra P3, $74 \mathrm{ka}$; los rangos de etapas de isotopía de oxígeno oscilaron entre 3-5 OIS (por sus siglas en inglés). Estas edades de las arenas eólicas que se intercalan con los sedimentos de los abanicos, resultaron ser más antiguas de lo esperado, lo que demuestra que el sistema de abanicos sirve de basamento a la Ciudad que terminó su proceso de sedimentación en el Pleistoceno tardio. Es decir, después de lo que se interpreta como un intenso periodo de erosión, sin más depósito durante el periodo Pleistoceno Tardio - Holoceno. Estas tres edades corresponden a periodos glaciales globales secos y frios, que produjeron el transporte de arenas eólicas en el norte de México. Posteriormente se produjeron fases de clima 
húmedo que activaron la erección de los abanicos. Estos se intercalan con sistemas fluviales y terrazas derivadas del Río Bravo, lo que indica una componente de disección debido a la erosión lateral del río que estuvo activa durante edades tempranas a las registradas en las muestras datadas (OSL). Sin embargo, esto no está aún determinado y se requiere una futura datación del sistema de abanicos.

Palabras clave: luminiscencia, norte de México, Ciudad Juárez, abanicos aluviales.

\section{Introduction, previous research, and study purpose}

The alluvial fan system located beneath and around Ciudad Juárez, Chihuahua, northern México (Figure 1) developed during the late Tertiary to Quaternary throughout the southwestern USA and northern México region. Much research has been published (in the USA) about the history of the Río Grande, with key papers published by Hawley et al. (1976) and Mack et al. (2006). However, there is little knowledge of the southern continuation of the system into northern México where the Río Grande is called the Río Bravo. This paper presents the first attempt to link the chronological processes of the alluvial system in the Ciudad Juárez area to USA sites, using Optically Stimulated Luminescence (OSL) dating, and aims to advance understanding the history of the alluvial fan depositional system of northern México.

There is a globally recognized need to understand the behavior of regional scale alluvial fan systems due to flood risk and sediment transport associated with climate change. Furthermore, understanding the regional effects of climate on alluvial fan deposits is a key research frontier (Owen et al., 2014). However, little previous research has been conducted on Mexican regional alluvial fans. Sparsely inhabited areas of the El Fresnal Playa within the Los Muertos Basin, about $100 \mathrm{~km}$ west-southwest of our study area in Chihuahua, have well-exposed sections that allowed Ortega-Ramírez et al. (2004) to identify three generations of apparent late Quaternary alluvial fans in the hanging wall and footwall of a major fault. In contrast, the high population density has limited the geologic outcrops in Ciudad Juárez. Although small road cuts are abundant across the fans and expose undisturbed deposit outcrops, these outcrops cannot be easily correlated to build up a clear stratigraphic context for the fan history without geochronological age control. Studies using modern geochronological tools, such as those presented here, are critical for reaching a better understanding of alluvial fan dynamics (Owen et al., 2014).

One such geochronological tool is OSL dating (Aitken, 1998; Rhodes, 2011). OSL dating involves measuring electrons that have been displaced by ionizing radiation and in the process became trapped in crystal lattice defects within a mineral (Huntley et al., 1985). The concentration of these electrons increases with time while buried and decreases while in sunlight (Gray and Mahan, 2015). This property has allowed grains of quartz and feldspar to be used as geo-chronometers for sedimentary units in a variety of geomorphic environments (Huntley and Johnson, 1976; Wintle and Huntley, 1979; Huntley et al., 1985; Rhodes, 2011). Quartz OSL is particularity useful in that the populations of electrons can be easily removed by sunlight such that there is a high probability of obtaining an accurate age. This is advantageous for alluvial fans where deposition can occur during flash floods, which have limited light exposure for sedimentary grains. Additionally, robust statistical techniques such as the Minimum-Age-Model (MAM) can be used to further control for the uneven light exposure of grains (Galbraith et al., 1999).

In an effort to establish these stratigraphic correlations and obtain age control, we present three new OSL dates on sediment in the alluvial fan system. We use these data to constrain the ages of formation of the fans and discuss the implications of these dates in relation to regional fan processes and late Quaternary climate. This study will also help improve understanding of the recent geological history of the region in order to place the current problems of flooding in Ciudad Juárez into context. This is part of long-range planning for mitigation of the frequent floods affecting Ciudad Juárez (Esparza et al., 2007).

\section{Río Bravo and fans: features and geological setting}

The pre-Neogene drainage network of the study area was derived during the compressive Laramide orogeny during Paleocene to Eocene time. After that, deformation of Cretaceous rocks created a synclinorium structure and four thrust sheets (oriented NW) were emplaced in the area and formed the rock massif now represented as the Juárez Mountains. Then, during Eocene to Oligocene time, intrusive and extrusive andesite rocks were deposited at the surface. Therefore, many reverse, normal and oblique faults typical of the Basin and Range physiographic province were created at this time, in probable response to magmatic events and these faults extend across Chihuahua State, Ciudad Juárez, El Paso (Texas) and New México (García, 1970; Wacker, 1972; Nodeland, 1977; Drewes and Dryer, 1993; Carciumaru and Ortega, 2008). During this time, the ancestral Chihuahua trough was destroyed and its deposits were transported, filling the northern Hueco and Mesilla bolsons, which form typical Basin and Range intermontane basins. Upon this antecedent surface, alluvial fans have been developed, generating the topography upon which Ciudad Juárez is constructed. 


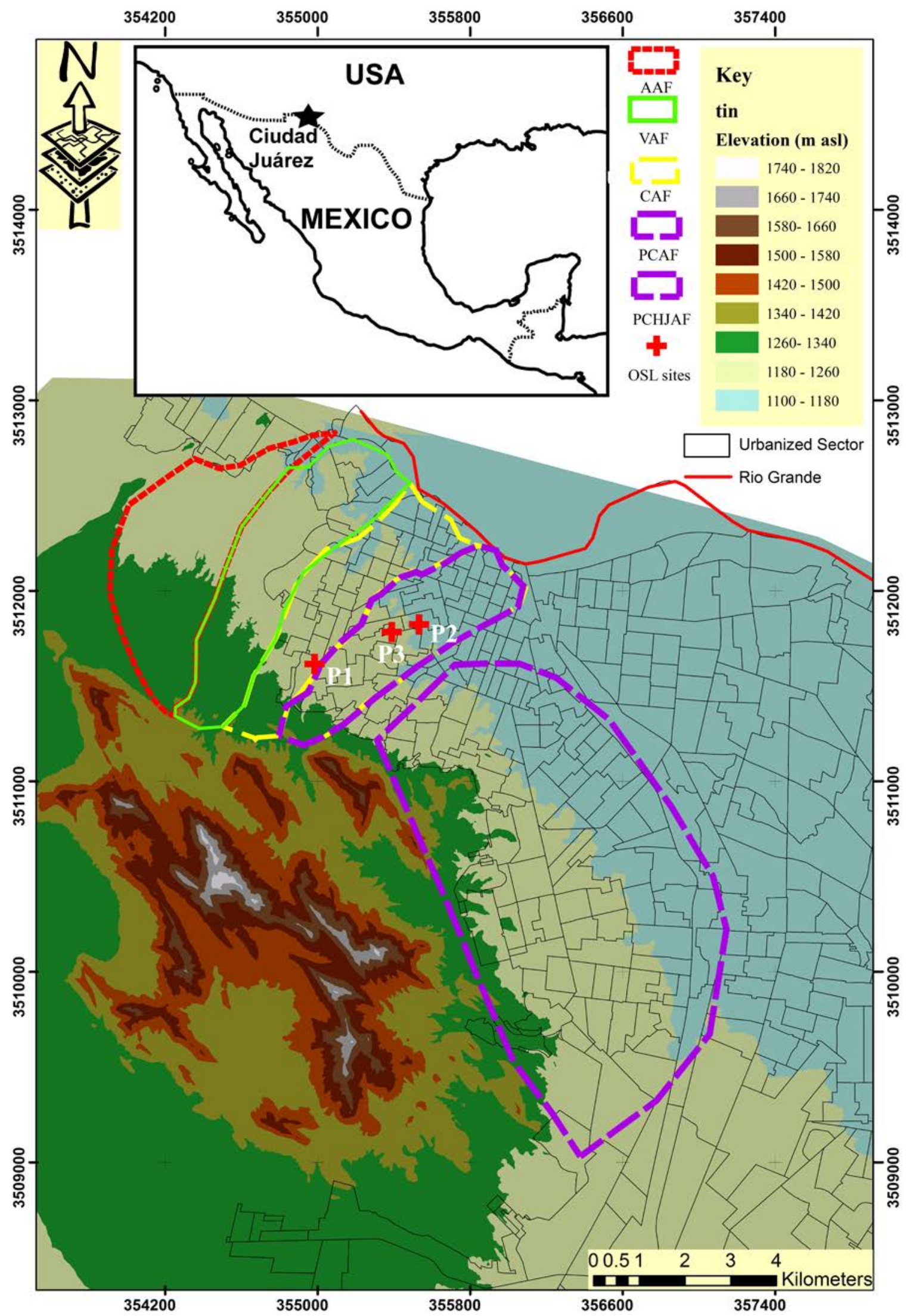

Figure 1. Location of Ciudad Juárez, northern México (inset map). Main figure shows Digital Elevation Model, created in Arc-GIS 10.2, of the study area: tin $=$ triangulated irregular network; $\mathrm{AAF}=$ Anapra Alluvial Fan; VAF $=$ Víboras Alluvial Fan; $\mathrm{CAF}=$ Colorado Alluvial Fan; PCAF $=$ Piedmont Colorado Alluvial Fan; PCHJAF = Palo Chino and Jarudo Alluvial Fan. Solid red line = Río Bravo. 
The geomorphic evolution is spatially and temporally associated with both, tectonic and climatic controls. Downfaulted areas produced basins, which accumulated the sedimentary Lower, Middle and Upper Santa Fe Formations in the Hueco and Mesilla bolsons (Hawley and Kottlowsky, 1969; Hawley et al., 1976). Furthermore, recent tectonic and/or climatic events associated with the arrival of major ephemeral distributaries of the Río Bravo during Pleistocene to Holocene time likely produced river terraces. Finally, ages of ash derived from Lava Creek B (from the Yellowstone volcanic system), preserved in the highest layer $75 \mathrm{~m}$ above the Río Bravo floodplain, in the area of the University of Texas at El Paso (near Mesa Street), demonstrate incision of the Río Bravo channel around 660 ka before present along the Paso del Norte between the Franklin Mountains and the Sierra de Juárez uplift (Hawley and Kottlowsky, 1969; Hawley et al., 1976).

\section{Río Bravo system evolution during early Pleistocene to Holocene time:}

The Río Bravo system and surrounding mountain streams were developed during Pliocene-Pleistocene to Holocene time (Mack and Seager, 1990, 1995; Mack et al., 2006) leaving a varied regional landscape which can be broadly divided into three major areas (Figure 1): A) The northwest sector composed of the Anapra alluvial fan, where the fan processes are active transporting sediment via ephemeral streams. There is little human modification in this area, with only one major protective structure (the Benito Juárez dyke) to prevent flooding in the lower reaches of the fan. Otherwise, there is no interruption of natural processes. Sector B) the central sector comprised of: West Snake Stream; East Snake Stream (VAF on Figure 1); the alluvial fan called Colorado Alluvial fan (CAF) and the piedmont mountain front fan system (PCAF; Figure 1); finally, sector $\mathrm{C}$ ) The southeast sector, which integrates the Palo Chino (PCH) and Jarudo fan system (PCHJAF; Figure 1). Sectors B) and C) are areas of major construction of buildings and roads.

In the streams, numerous minor dykes trap downstream movement of floodwater and alluvial sediment; and many streams are lined and shaped with concrete and act as both roadways and flood spillways. Therefore in these sectors, the natural fan processes are severely interrupted, and fan action does not operate in its normal mode. However, despite recent human interruptions of fan processes, there is evidence, produced by new dates, that the fan system was also interrupted naturally by dissection and lateral erosion in the Late Pleistocene. The lower parts of the fans were subsequently covered by Río Bravo sediments, which were later eroded to form terraces, broadly correlating with documented Pleistocene to Holocene climatic processes of New México and El Paso, Texas (Mack and Leeder, 1998). It is worth noting that Mack and Leeder (1998) commented that the Río Bravo is a special case, because channel migration and avulsion were frequent, and these processes might impact the degree of intercalation between the river and alluvial terrace sediments.

Figure 1 shows a Digital Elevation Model (DEM) of the study area with the distribution of alluvial fans derived from the Juárez Mountains. OSL ages were obtained from the CAF (Figure 2). At least five shifts of the Río Bravo tributaries occurred during Pleistocene to Holocene time, providing these possible scenarios: i) the Cabeza de Vaca Lake of Plio-Pleistocene time (>2.5 Ma) (Strain, 1966; Hawley and Kottlowsky, 1969; Vanderhill, 1986; Gustavson, 1991); ii) the ancestral Río Bravo path changed again during the Middle to Late Pleistocene (0.66 Ma to $0.16 \mathrm{Ma}$ ); iii) the older Río Bravo tributaries built a dissected terrace during Late Pleistocene time ( 0.16 to $0.10 \mathrm{Ma}$ ) (Connell et al., 1998); iv) another terrace system was formed during Late Pleistocene time from 78 to $28 \mathrm{ka}$ (Connell et al., 1998) and again from 15 to $22 \mathrm{ka}$ (Hawley and Kottlowsky 1969; Hawley et al., 1976; Allen and Anderson, 1993). During this period of time, younger Río Bravo tributaries were active again. Finally, v) from $15 \mathrm{ka}$ to the present, the last shift of the Río Bravo has been in progress. Connell and Love (2001) described a series of late Quaternary sands and gravels deposited above the Santa Fe Group (making them Post-Santa Fe Group sediments). These form a series of river terraces adjacent to the modern Río Grande in New México. Of interest to our study, the upper terraces (informal depositional units Qra and Qay of Connell and Love (2001)) are approximately age-equivalent to the dates that we have obtained from the alluvial fans above the Ciudad Juárez (see Figures 3 and 6 of Connell and Love, 2001) noting that these authors did not provide numerical ages).

\section{Methods}

Fan distribution was studied and mapped using a combination of field observations and GIS-based topographic mapping, with the caveat that comprehensive fieldwork in the Ciudad Juárez area is precluded by the largescale ground coverage of buildings and roads. Mapping was used to determine the most appropriate locations for OSL sediment sampling (Personius and Mahan, 2000, 2003; Nelson et al., 2015). OSL was applied to samples collected from three specific sites mostly composed of fine aeolian quartz sands (see Figures 3A-C). The samples were collected by the first author using the procedure recommended in Cole et al. (2007). Care was taken to keep the samples light-tight during collection and shipment to the OSL laboratory. The samples were processed using protocols set forth in Gray et al. (2015). We used the $250-180 \mu \mathrm{m}$ fraction because this one yielded the largest amount of quartz particles useable of the sample. However, even using this largest fraction of quartz, we were limited in the number of aliquots available 


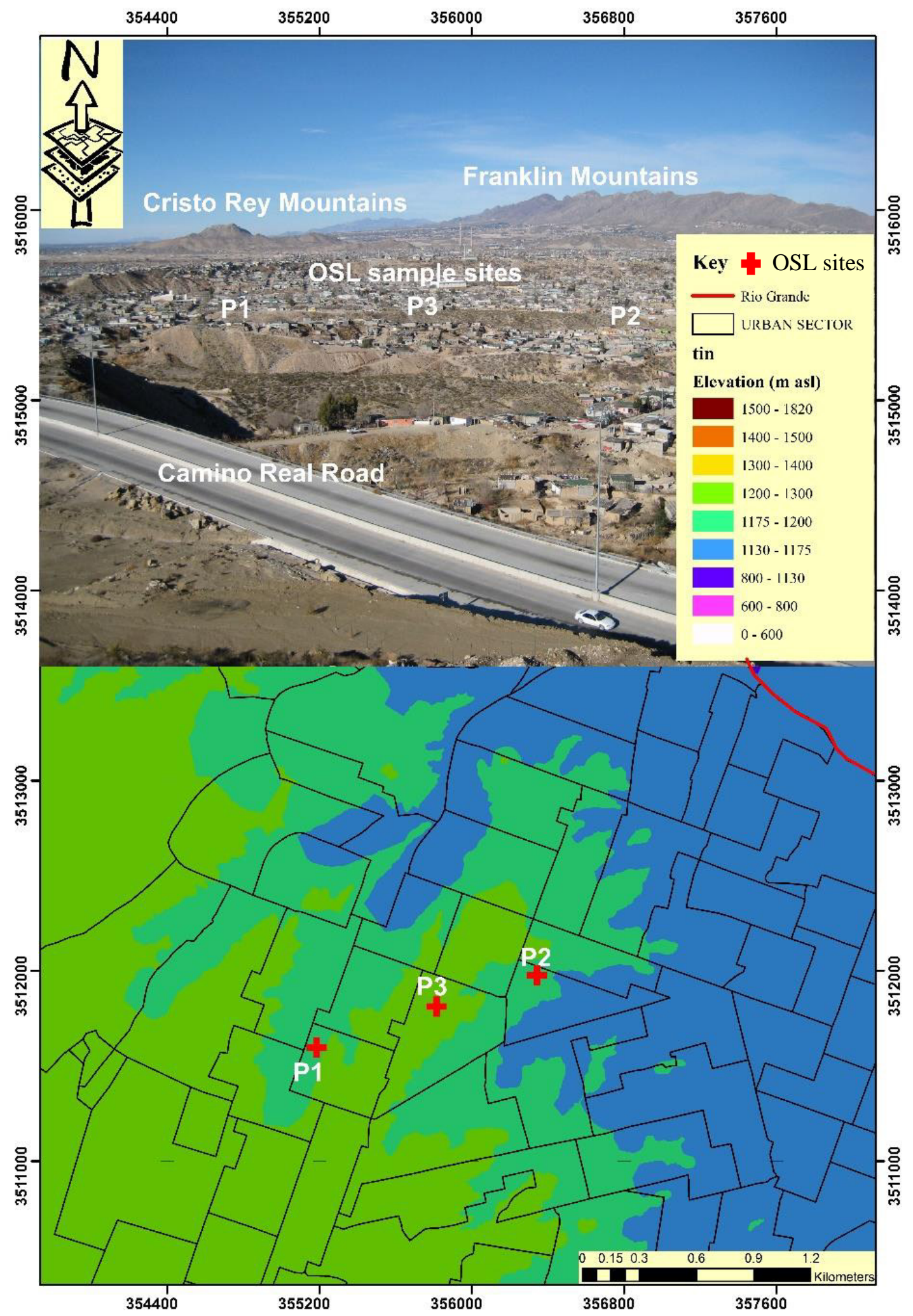

Figure 2. Upper: photograph looking north, of study area from the hill above Camino Real, showing the Colorado fan where samples for OSL dating were collected. Lower: Detail of DEM created in Arc-GIS 10.2 and showing positions of OSL samples; "tin" = triangulated irregular network. 
for analysis due to small quartz yields in the lab. Samples were treated to standard $\mathrm{HCl}, \mathrm{H}_{2} \mathrm{O}_{2}$, and $\mathrm{HF}$ treatments, magnetic and density separation, and dose rates were measured using gamma spectrometry at the U.S. Geological Survey TRIGA facility (Gray et al., 2015) cosmic ray contribution to dose rate for luminescence was achieved using the method of Prescott and Hutton (1994).

As noted above, a key problem in fan analysis is that the system has been dissected and extensively covered by the modern development of Ciudad Juárez. Determining detailed geometric relationships between the various parts of the fans is effectively impossible. However, it is expected that the uppermost exposed deposits at any site will provide the best opportunity to assemble age data for more recent fan evolution. Consistency of the material was achieved by sampling of aeolian sands at all the three sites. In each outcrop location, the local stratigraphy shows that the sands sampled for OSL dating are overlain by conglomerates (see Figures 3A-C) so episodes of aeolian deposition were followed by renewed fan building activity. The three sample sites help to constrain the overall general history of the alluvial fans but are specifically tied to the CAF, which was selected in order to understand the most recent history of the fan system. Therefore, aeolian layers should be the best candidates for a complete bleaching during the depositional processes and would function as proxies for arid or windy period. Samples were collected at the following sites on the CAF (see Figure 2):

P1 collected at 13R: 354,694.63 m E; UTM 3,512,048.16 $\mathrm{m}$ W; elevation 1252 masl.

P3 collected at 13R: 355,593.59 m E; UTM 3,512,861.18 $\mathrm{m}$ W; elevation 1201 masl.

P2 collected at 13R: 355,730.21 m E; UTM 3,512,678.11 $\mathrm{m} \mathrm{W}$; elevation 1241 masl.

\section{Results}

The OSL data (Table 1) and results (Figure 4) show the ages distribution for the three sites on the CAF. The most notable result from the OSL analyses is that, there are two sediment populations in the two younger samples. Furthermore, the oldest sediment populations can be observed in each of the succeeding samples. Sample P1 (S1) shows a population at $31 \mathrm{ka}$ and another population at $45 \mathrm{ka} \mathrm{P1}$ (S2) while sample P2 shows a population at $41 \mathrm{ka}$ (S1) and a second, older population at $69 \mathrm{ka}(\mathrm{S} 2)$. This 69 ka population overlaps with the population measured from the oldest sample P3 (S1)) at $74 \mathrm{ka}$ (see Table 1).

The results coincide with the period of time covering Oxygen Isotope Stages (OIS) 3 to 5 as follows: samples P1 was measured at 30 and $45 \mathrm{ka}$ (late OIS Stage 3), samples P2 was measured at 41 and $69 \mathrm{ka}$ (around the boundary between OIS 4 and 3), and sample P3 was measured at 74 ka (very latest OIS 5a). These ages represent deposition during both glacial and interglacial phases.

The sample with the tightest equivalent dose distribution was P3 (Table 1). However, P3 is also the oldest sample and came very close to having all quartz OSL trap sites completely filled (usually quartz saturates around 150 200 Grays in traditional OSL measurements; Mahan et al., 2015). The two younger samples were not saturated for two reasons: firstly, because the growth curves (see Figures $4 \mathrm{~A}, 4 \mathrm{~B}, 5 \mathrm{~A}$ and $5 \mathrm{~B}$ and table 5 of supplementary material) did not exhibit saturation behavior and secondly because the dose rate was moderate enough (2.80 to $3.26 \mathrm{~Gy} / \mathrm{ka})$ to allow natural accumulation to occur for some length of time (Table 1). The quartz in sample P3 was approaching to saturation at 208 Grays, so this age could be even older, but is certainly not younger than $74 \mathrm{ka}$ (Figure 6B of supplementary material). P1 and P2 have two equivalent dose populations with correspondingly higher dispersions, close to or over $30 \%$ to $40 \%(\mathrm{P} 1=29 \%$ and $\mathrm{P} 2=39 \%$; (see Table 1).

It is not entirely unexpected to have several populations of grains within poorly sorted alluvial fans sediment (Mahan et al., 2007, 2015; Miller et al., 2010) due to loose sand and gravel packing, fluvial reworking; partial bleaching, due to rapid depositional processes, or reactivation of unconsolidated or uncemented sediment layers. However, the aeolian sediment within the alluvial fan material is most appropriate for OSL dating because the nature of these deposits ensures that maximum exposure to sunlight before deposition occurred (Bateman et al., 2012) and because targeting finer-grained layers within the fan also increases the chances that a majority of the sediments were zeroed or bleached before final deposition.

\section{Discussion}

Relict topography has influenced the alluvial and fluvial history of the study area, producing a complex sedimentary system comprised of river sediments from the Río Bravo in the northeast, and the alluvial fan material derived from the Juárez Mountains in the southwest. The timing and extent of the inter-fingering of the Río Bravo terrace sediments with the Juárez Mountains alluvial material is currently unknown and represents an area for future exploration; we will concentrate on evidence provided by the OSL ages and what they indicate about alluvial fan incision and aggradation. Corroborating evidence for substantial, long-term erosion of the fans, using the OSL dates presented in this paper, is shown in Figure 6, where it can be seen that the fans are incised to a substantial degree, so that the city is built on an eroded fan surface. Furthermore, it is possible that increased Holocene aridity, developed after and throughout the last glacial phase, may have led to substantial degradation of the fans. 

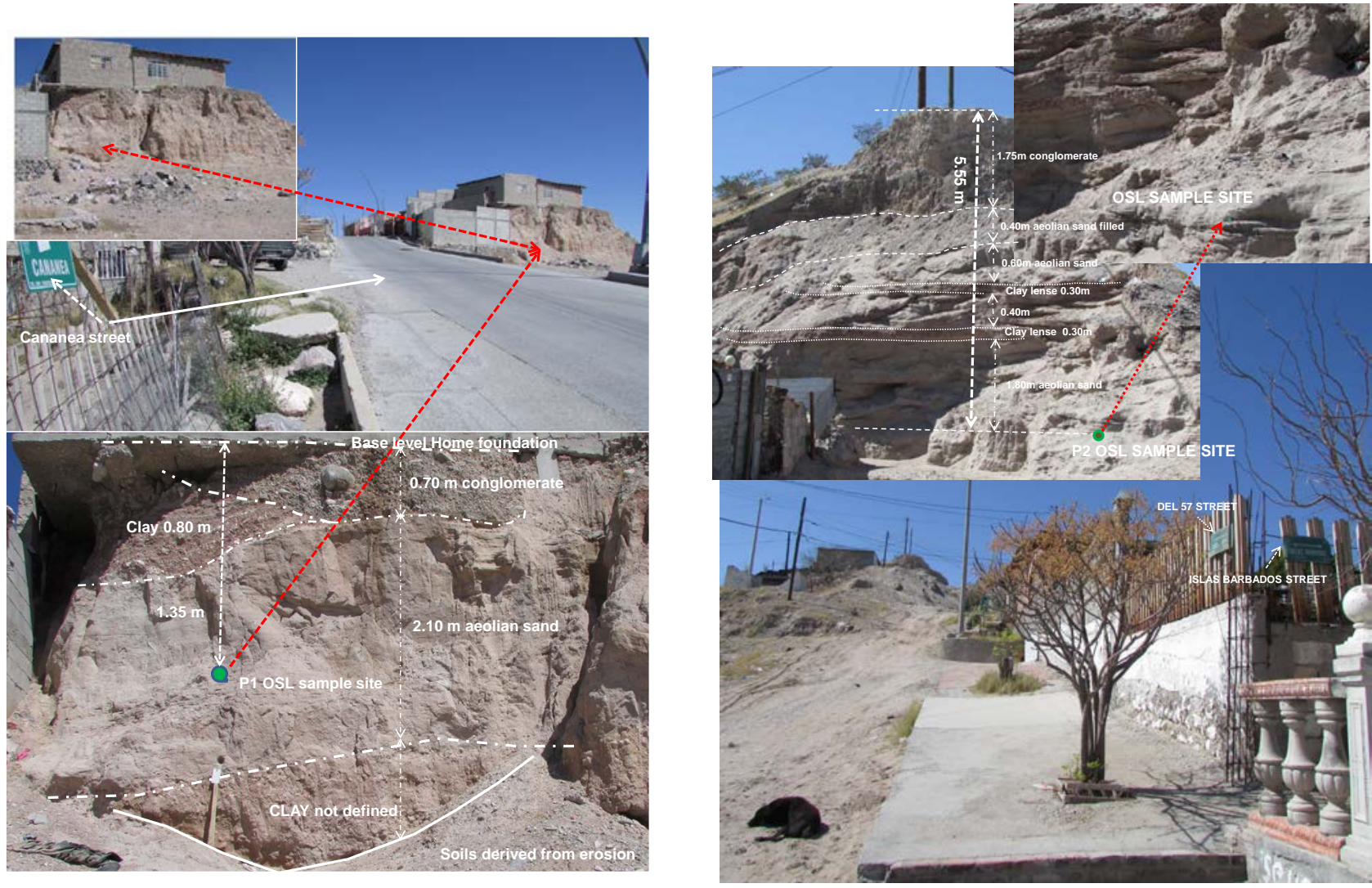

A (P1)

\section{B (P2)}

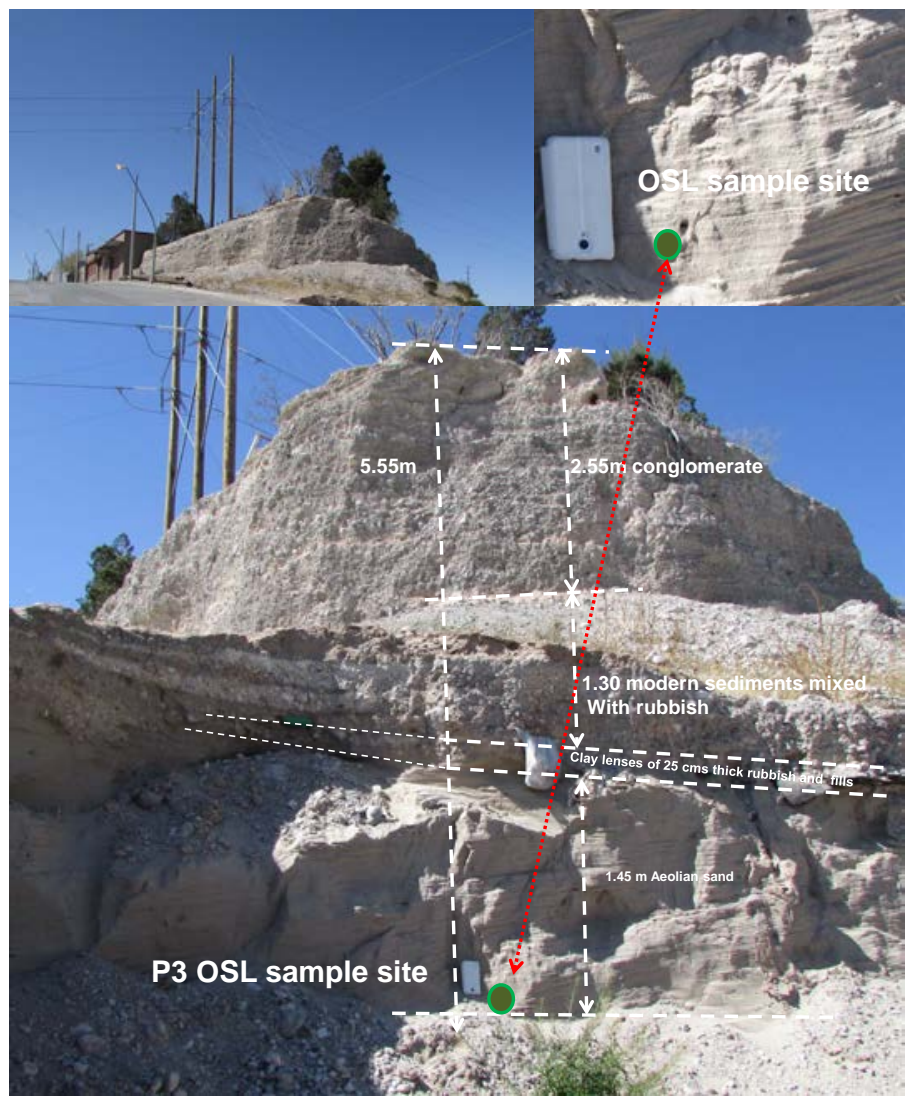

C (P3)

Figure 3. Photos of the three sample sites demonstrating collection from aeolian sand lenses. A, B and C are samples P1, P2 and P3 respectively. 
Table 1. OSL data showing age results for all three samples. See text for description and discussion.

\begin{tabular}{|c|c|c|c|c|c|c|c|c|c|}
\hline $\begin{array}{c}\text { Sample } \\
\text { ID }\end{array}$ & $\begin{array}{c}\text { \% Water } \\
\text { Content }\end{array}$ & $\mathrm{K}(\%)^{\mathrm{b}}$ & $\mathbf{U}(\mathbf{p p m})^{\mathbf{b}}$ & Th $(\mathrm{ppm})^{\mathrm{b}}$ & $\begin{array}{c}\text { Total Dose } \\
\text { Rate }(\mathrm{Gy} / \mathrm{ka})^{\mathrm{c}}\end{array}$ & $\begin{array}{l}\text { Equivalent } \\
\text { Dose (Gys) }\end{array}$ & $\mathbf{N}^{\mathbf{d}}$ & $\%$ Scatter $^{\mathrm{e}}$ & $\begin{array}{l}\text { Age } \\
(\mathbf{k a})^{\mathrm{f}} \\
\end{array}$ \\
\hline \multirow[t]{2}{*}{ P1 } & $1(32)$ & $2.28 \pm 0.03$ & $1.32 \pm 0.07$ & $4.25 \pm 0.24$ & $3.01 \pm 0.10$ & $93.2 \pm 2.26$ & $10(30)$ & 29 & $30.9 \pm 1.24$ \\
\hline & & & & & & $135 \pm 4.54$ & $16(30)$ & 29 & $44.9 \pm 2.08$ \\
\hline \multirow[t]{2}{*}{ P2 } & $1(32)$ & $2.65 \pm 0.07$ & $1.09 \pm 0.15$ & $4.97 \pm 0.37$ & $3.26 \pm 0.13$ & $134 \pm 5.39$ & $9(30)$ & 39 & $41.1 \pm 2.30$ \\
\hline & & & & & & $225 \pm 11.3$ & $14(30)$ & 39 & $69.0 \pm 4.38$ \\
\hline P3 & $1(35)$ & $2.24 \pm 0.05$ & $0.96 \pm 0.11$ & $4.21 \pm 0.33$ & $2.80 \pm 0.11$ & $208 \pm 8.53$ & $15(15)$ & 10 & $74.3 \pm 4.29$ \\
\hline
\end{tabular}

a Field moisture, with figures indicating the complete sample saturation \%. Ages calculated using approximately $15 \%$ of total measured saturation. ${ }^{\mathrm{b}}$ Analyses obtained using laboratory gamma spectrometry (high-resolution Ge detector).

'Includes cosmic dose rate of $0.23 \mathrm{~Gy} / \mathrm{ka}$ for P1, $0.13 \mathrm{~Gy} / \mathrm{ka}$ for P2, and $0.15 \mathrm{~Gy} / \mathrm{ka}$ for P3 (using methods of Prescott and Hutton, 1994; depth and attentuation)

${ }^{\mathrm{d}}$ Number of replicated equivalent dose (De) estimates used to calculate the age. Figures in parentheses indicate total number of measurements included in calculating the represented De and age using the central age model (CAM; bottom age) and the minimum age model (MAM; top age). Preferred ages in bold font.

eDefined as "overdispersion" of the DE values. Obtained by taking standard deviation over the average. Values $>30 \%$ reflect poorly bleached or mixed sediments.

${ }^{\mathrm{f}} \mathrm{Age}$ for $250-180$ microns quartz sand. Exponential fit used on equivalent dose, errors to one sigma.
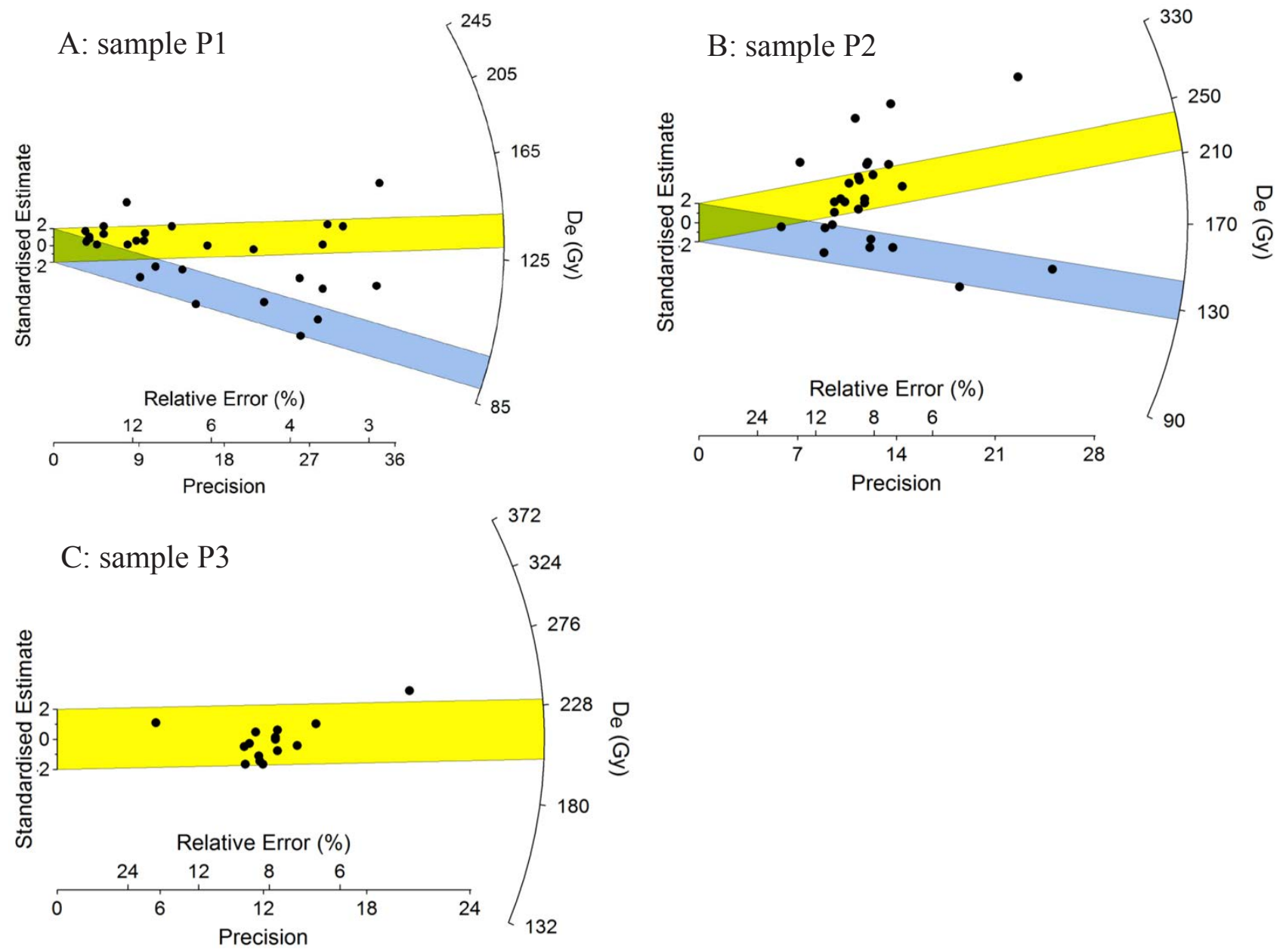

Figure 4. OSL age plots. A-C: radial plots for samples P1-P3 respectively.

6.1. Ciudad Juárez alluvial fan age

The younger of the two ages of P1 and P2 are more reliable than the older ages of these two samples, and the younger dates are obtained using a (MAM) (Galbraith et al., 1999). The MAM thus marks three episodes of 


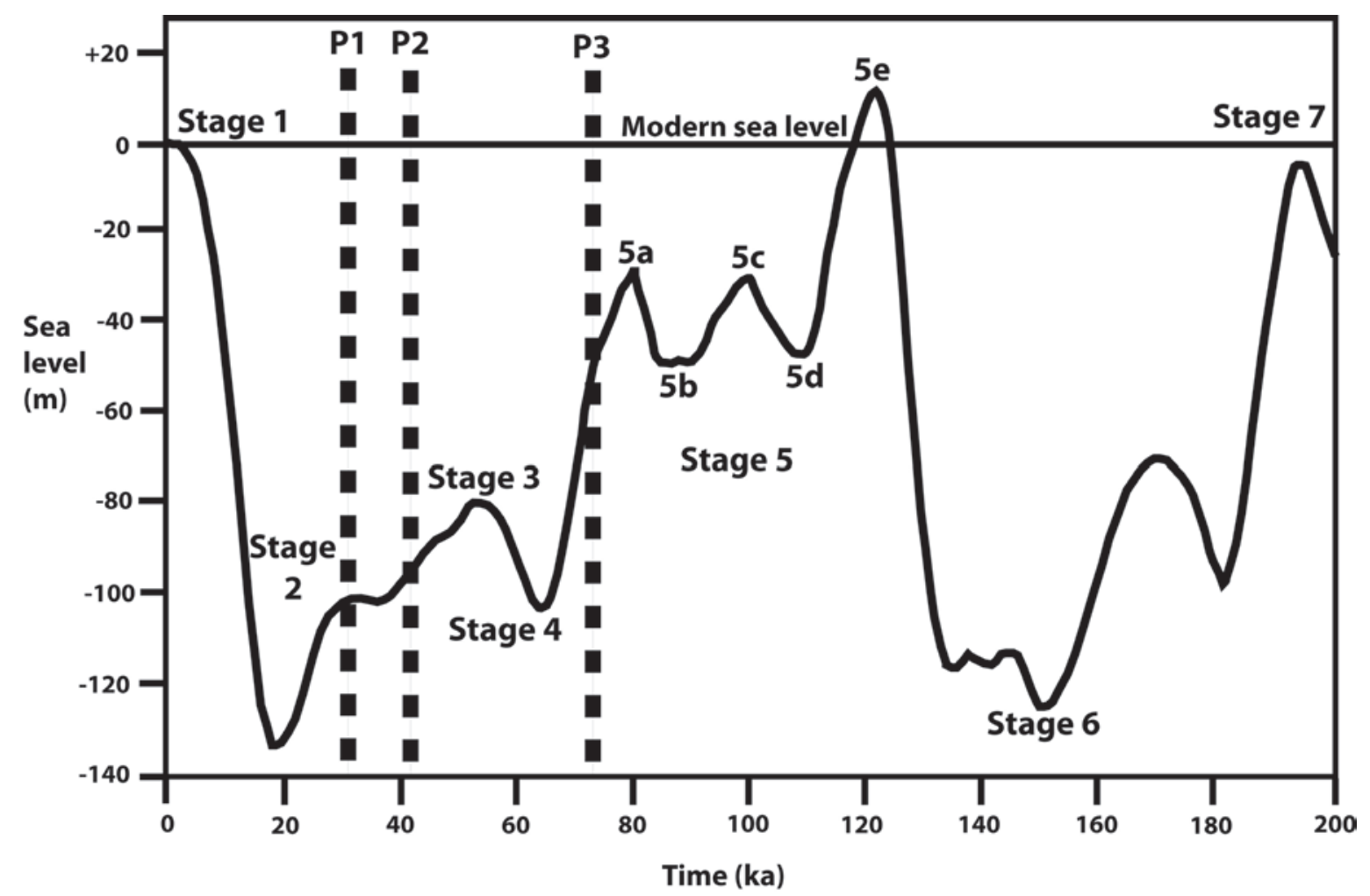

Figure 5. Oxygen Isotope Curve for the last $100 \mathrm{ka}$, showing the relationship between OIS stages and the dates of the three samples from Ciudad Juárez described in this paper.

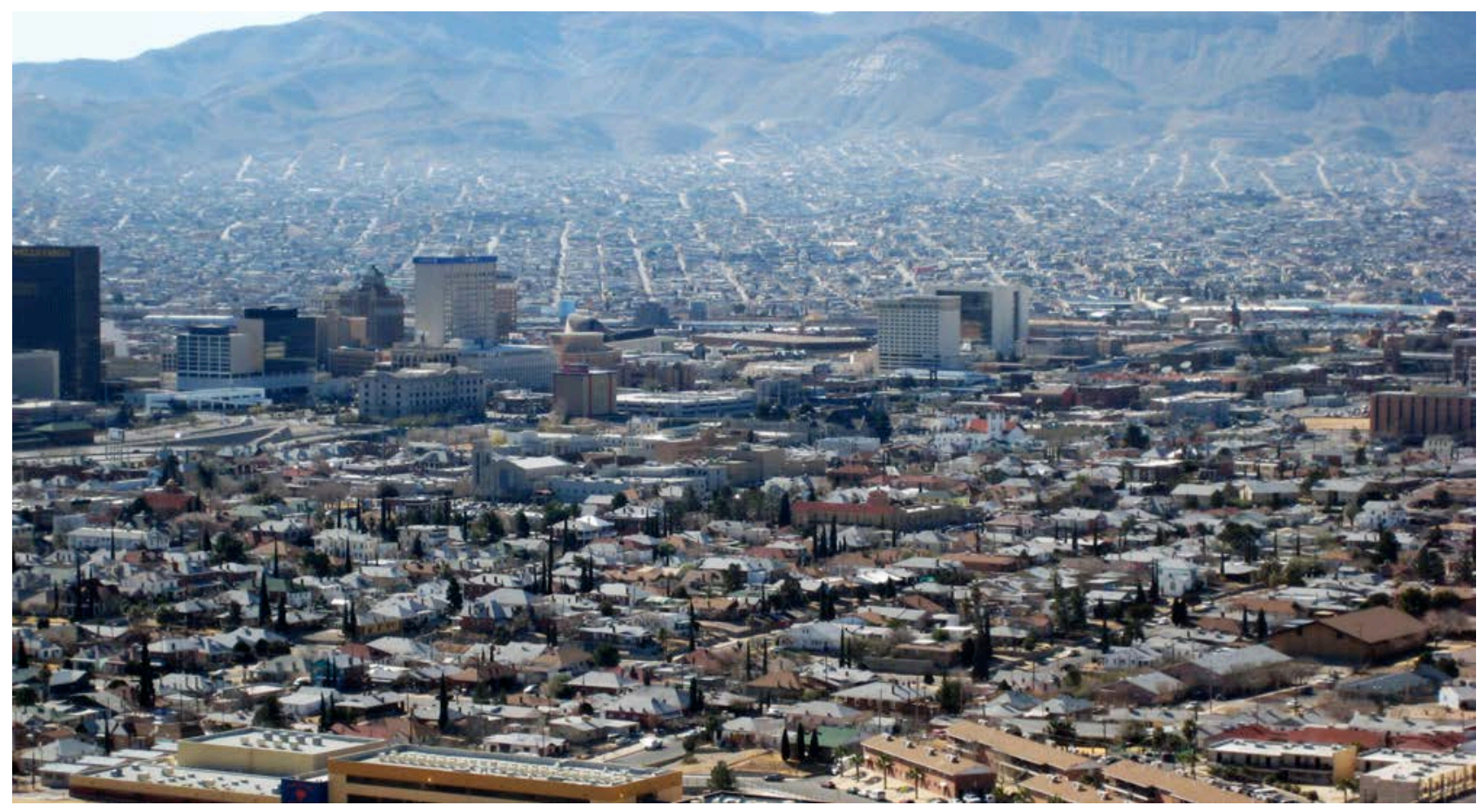

Figure 6. Photograph looking across El Paso to Ciudad Juárez; the border lies just beyond the high-rise buildings in the middle of the picture. Note that on the Mexican side, the gridded road system is developed across a largely planated surface of the older parts of the fan system, providing geomorphological evidence for a long period of erosion following the youngest OSL date presented in Figures 5 and 6. 
aeolian deposition (at approximately $30 \mathrm{ka}, 40 \mathrm{ka}$ and $75 \mathrm{ka}$ ) contained within the uppermost (youngest) fan structure. At least three explanations for the deposition and the preservation of the sands are possible: A) sediment became available early in the two last glacial maxima, when there was more erosion of the highlands due to increased moisture, so that when arid periods impacted the basin there was a ready supply of sand to be deposited on the fans (Ellwein et al., 2011, 2015); B) dust or sediment became available because of dune activation or reactivation of the easily deflated playa, river terrace, and lower alluvial fan sediments (Muhs, 2013). It is possible that these periods contain episodes of low effective moisture and high dust accumulation due to drying winds as the glacial phase develops, in which case the formation of aeolian sands for P1 and P2 match global climate changes. However, this is a broad interpretation, and it is more likely that there were C) simply more localized controls operating in this region, such as vegetation and wind shifts (Cole et al., 2007; Hall et al., 2008).

Vegetative cover change was highlighted by Harvey et al. (1999) where attention was drawn to the differences in erosion characteristics of late Quaternary fans in California, which are influenced by the degree to which they are covered by vegetation. In the Ciudad Juárez area, throughout the fan system sparse vegetation is obvious, and it has proved difficult to find outcrops or cores containing pollen, seeds, or other physical evidence that the region was previously well vegetated. Ceballos et al. (2010, Figure 6) provided maps of Pleistocene vegetation throughout México, and identified xeric scrub as the dominant vegetation in the Ciudad Juárez study area, indicating poorly developed land cover only minimally sufficient to support a land mammal migration corridor between northern central México and southern central USA. Thus, erosion may be sustained in the highlands of the Juárez Mountains leading to aggrading fan development in the late Quaternary, with subsequent erosion in more recent times in the lower Juárez Mountains. Furthermore, there are studies of global teleconnections that suggest monsoon rains during the late Quaternary glaciation and possibly earlier (Coats et al., 2008; Miller et al., 2010; Muhs, 2013) along the Pacific coasts of North America, which would be compatible with shifts between aeolian and conglomeratic deposits in the Ciudad Juárez fans.

Unfortunately, because of the urban sprawl of buildings and roads, the history of the fans cannot be fully determined, but one key point emerges: the OSL dates reveal that the sand has older ages than expected, and suggest that large parts of the fan system became inactive, with the youngest preserved activity being around $30 \mathrm{ka}$. The amount of erosion on the fans cannot be totally known, and so it remains possible that the fans could have aggraded in the Holocene, with subsequent erosion. To avoid the problem of younger aggradation and subsequent removal, however, the samples were collected from the highest preserved points where it is not likely to have been easily eroded (Figures 1,
2 and 6, for visual inspection of the geomorphic relationship between the fans and the surrounding hills).

In more recent times, the alluvial system was partly reactivated in the Anapra fan. The Anapra fan is active in the north part of the study area and this observation suggests shifting of fan aggradation, while abandoning the older parts (where the city is built). It is reasonable to presume, from the geometry and activity of the Anapra fan (Figure1) and the continued flooding of the city after heavy rainfall events that the hydrological system has been intermittently to continually active through the Pleistocene to modern time, but has shifted position, abandoning the older fan system by starving it of sediment. The older (OSL dated) fans were likely degraded by more recent erosive activity but this cannot be satisfactorily investigated because of the paucity of outcrops in the city. Although making overall interpretations from only three dates is tenuous, these dates do provide valuable preliminary constraints on the history of the area.

\subsection{Comparison with other alluvial fans and climate}

Comparison between the three OSL ages and the pattern of the global oxygen isotope curve (Figure 5) shows that there is not a clear relationship between glacial/interglacial cycles and broad-scale regional sedimentary process in the northern México area. The proximity of the fans to the Juárez Mountains, and the repeated local stratigraphy in the three sample sites, suggests instead that localized climatic changes, perhaps influenced by the steep topography of the mountains and the prevailing winds (Muhs, 2013), were a major control on fan formation. It is possible that coolseason Pacific frontal storms caused river flow, ephemeral lakes, and fan incision, whereas periods of intense warmseason storms caused hillslope erosion and alluvial fan aggradation, as suggested by Miller et al. (2010) and Muhs (2013). Alternatively, the regional topography from the Juárez Mountains, across the Hueco Basin to the Franklin Mountains to the north, created a geographically constrained climatic environment that was locally more influential than the global glacial/interglacial cycles. Support for this suggestion comes from recent work on the Río Bravo terraces in the Albuquerque area of New México (Cole et al., 2007), which shows that there is no clear relationship between terrace age and climate in the Albuquerque area: dates on terraces from a variety of dating methods show scatter throughout OIS-6 to OIS-1, with no firm pattern. Furthermore, compilations of alluvial fan cosmogenic geochronology ages demonstrated no clear pattern with climate (Owen et al., 2014), further challenging the idea that alluvial fans are a climate indicator. Hall and Goble (2012, their Figure 2) described Late Pleistocene paleosols in New México, and measured two OSL dates $(81 \pm 6 \mathrm{ka}$ and $91 \pm 7 \mathrm{ka}$ ) for the lower aeolian sand deposited after the Mescalero paleosol, but before the Berino paleosol (this paleosol is dated as late OIS Stage 3 to early OIS Stage 
2). Thus the lower aeolian sand represents a dry period between two wetter periods as inferred for the paleosols. This aeolian sand is older than the Ciudad Juárez P3 sample at $74.3 \mathrm{ka}$ but the two do overlap within error at $75-79 \mathrm{ka}$. The aeolian sand from which P3 was collected is overlain by coarse-grained conglomerates that were presumably deposited by high or rapid water flow indicating a humid phase after aridity. Thus we make a tentative correlation between the oldest age of the three dates on Juárez fans on one hand, and depositional events in New México on the other, reflecting a regional climate feature.

McDonald et al. (2003) described the results of climate shifts between latest Pleistocene to Holocene in the Mojave Desert, California, highlighting the increase in wetness that spurred enhanced erosion and transport of sediment, leading to fan development. They also noted that aeolian and alluvial sediments in the region were deposited at approximately the same time, indicating widespread climate effects on erosion and sedimentation processes. Dorn (2009, Figure 24.1) drew attention to larger-scale climatic events in relation to the late Quaternary. In particular Dansgaard-Oeschger Cycles 11 and 12 from the Greenland ice cores that reflect moisture changes in the northern hemisphere are close in time to the Ciudad Juárez P2 sample. In contrast to interpretations of aridity discussed above for the 74 ka date in this paper, there is evidence in Greenland of temperature rise (implying increase moisture) in the study of Dansgaard-Oeschger cycles by Landais et al. (2004, see their Figure 3) at the same time, suggesting therefore that the Ciudad Juárez fans do respond to regional climate controls.

It remains unclear what the influence of short-term climate events, such as ENSO (El Niño - Southern Oscillation) episodes, is on the deposition of sediments in the Ciudad Juárez alluvial fans. Magaña and Conde (2000) demonstrated a tentative link between ENSO events and winter flooding in southern USA and northwestern México. On the other hand, Pavia et al. (2006) showed finer resolution of identification of wet phases involving both ENSO and Pacific Decadal Oscillations. Thus the Ciudad Juárez region may have been influenced more by Pacific than by Atlantic Ocean processes, and is an avenue for further investigation, although whether it will be possible to extend such interpretations back into the Pleistocene of the study area or not, remains an open question.

The implications of these results for the alluvial-fluvial system studied here in the Ciudad Juárez area provide an avenue for future work. Thus the OSL ages reported here may be indicators of climatic fluctuations in northernmost México through the late Quaternary that relate to broader scale climate changes, but so far our dated sediments do not allow a firm correlation with wider scale events, and change into the Holocene. Thus we regard our results as preliminary, but showing great promise, and emphasize the need for further dating work.

\section{Conclusions}

This study has provided the following outcomes:

1. The first numerical ages of quaternary alluvial fans in northern Mexico as measured by OSL in three samples are: a) sample $\mathrm{P} 1$ contains a minimum age (S1) of $31 \mathrm{ka}$ and a second population (S2) at 45 $\mathrm{ka}$; b) sample P2, a minimum age (S1) $41 \mathrm{ka}$ and second population (S2) at $69 \mathrm{ka}$; and c) sample $\mathrm{P} 3$ has one dominant population (S1) at $74 \mathrm{ka}$. We consider the younger of the two ages for P1 and $\mathrm{P} 2$ to be the more reliable. These ages are within the range of OIS 3 to 5. They demonstrate that fan development in the area, now occupied by the city, either terminated in the Late Pleistocene, after which there was apparently an extended period of aridity, or was not preserved when the Río Bravo incised the distal fan layers.

2. The oldest age (74 ka) corresponds to the developing glaciation of OIS Stage 4, but the younger two ages relate broadly to the development of the last glacial. These results imply that aridity was locally to regionally controlled, with limited evidence of a global overprint. However, this interpretation is tentative and further research is necessary. Alluvial fan margins inter-finger with fluvial terrace sediments derived from the Río Bravo indicating an additional component of fan dissection by the Río Bravo lateral erosion, presumed to be active during earlier times than our OSL ages, but these are not yet dated.

3. The age of the fans are broadly correlated with sand sheets and alluvial fans of other desert areas of the USA, including the Mojave Desert, and there are preliminary indications of relationships between the Ciudad Juárez fans and climate change in the region.

4. The fan system has been potentially reactivated to form the Anapra fan in the northern part of the study area, but detail is lacking because incision in the distal fans has been affected by the Río Bravo eroding the stratigraphy as the river changed course.

5. These preliminary dates provide an avenue of investigation for further dating to ascertain the controls on the alluvial fan and fluvial system.

\section{Acknowledgements}

We are grateful to the University of Ciudad Juárez for providing facilities for fieldwork in México. David Zúñiga thanks the administrators of the PROMEP program for support in the UK during his PhD study. Sampling for OSL dates was assisted by Hilario and Eduardo, and for their efforts we are most grateful. Steve Kershaw thanks Brunel University for support and use of facilities during the production of this paper. SAM thanks the U.S. Geological 
Survey for providing facilities for OSL dating. Any use of trade, product, or firm names is for descriptive purposes only and does not imply endorsement by the U.S. Government.

\section{References}

Aitken, M.J., 1998, An Introduction to Optical Dating: Oxford, England, Academic Press, $267 \mathrm{p}$.

Allen, B.D., Anderson, R.Y., 1993, Evidence from western North America for rapid shifts in climate during the last Glacial Maximum: Science, 260, 1920-1923.

Bateman, M.D., Bryant, R.G., Foster, I.D., Livingstone, I., Parsons, A.J., 2012, on the formation of sand ramps: A case study from the Mojave Desert: Geomorphology, 161, 93-109.

Carciumaru, D., Ortega, R., 2008, Geologic structure of the northern margin of the Chihuahua trough: Evidence for controlled deformation during Laramide Orogeny: Bulletin of the Mexican Geological Society, 60, 43-69.

Ceballos, G., Arroyo-Cabrales, I.A., Ponce, E., 2010, Effects of Pleistocene environmental changes on the distribution and community structure of the mammalian fauna of México: Quaternary Research, 73, 464-473.

Coats, L.L., Cole, K.C., Mead, J.I., 2008, 50000 years of vegetation and climate history on the Colorado Plateau, Utah and Arizona, USA: Quaternary Research, 70, 322-338.

Cole, J.C., Mahan, S.A., Stone, B.D., Shroba, R.R., 2007, Ages of Quaternary Río Grande terrace fill deposits, Albuquerque area New México: New México Geology, 29, 122-132.

Connell, S.D., Love, D.W., 2001, Stratigraphy of middle and upper Pleistocene fluvial deposits of the Río Grande (Post Santa Fe Group) and the geomorphic development of the Río Grande valley, northern Albuquerque basin, central New México: New México Bureau of Geology and Mineral Resources, Open File Report 454C, C1-C12.

Connell, S.D., Allen, B.D., Hawley, J.W., 1998, Subsurface stratigraphy of Santa Fe Group from borehole geophysical logs, Albuquerque Area, New México: New México Geology, 20, 2-7.

Dorn, R.I., 2009, The role of climatic change in alluvial fan development, in A.J., Parsons, A.D., Abrahams (eds.), Geomorphology of Desert Environments, 2nd ed., Springer Science, Business Media B.V. 2009, part VIII, 723-742

Drewes, H., Dyer, R., 1993, Geological map and structure sections of the Sierra Juárez, Chihuahua, México, 1-2287, 1:12500: Department of the Interior, U.S. Geological Survey Miscellaneous Investigations, 1 map.

Ellwein, A.L., Mahan, S.A., McFadden, L.D., 2011, New optically stimulated Luminescence ages provide evidence of MIS3 and MIS2 eolian activity on Black Mesa, northeastern Arizona, USA: Quaternary Research, 75, 395-398.

Ellwein, A.L., Mahan, S.A., McFadden, L.D., 2015, Impacts of climate change on the formation and stability of late Quaternary sand sheets and falling dunes, Black Mesa region, southern Colorado Plateau, USA: Quaternary International, 362, 87-107.

Esparza, E., Granados, A., Salas-Plata, J., Domínguez, A., 2007, Geospatial Modeling for a Surface Hydrology Analysis in the West part of the Sierra de Juárez Chihuahua, México (abstract), in Carbondale UCOWR conference: Illinois, Southern Illinois University Conference Proceedings, 7-25-2007.

Galbraith, R.F., Roberts, R.G., Laslett, G.M., Yoshida, H., Olley, J.M., 1999, Optical dating of single and multiple grains of quartz from minimum rock shelter, northern Australia: Part I, experimental design and statistical models: Archaeometry, 41, 339-364.

García, R., 1970, Geology and Petrography of Andesite intrusions in and near El Paso, Texas: El Paso, Texas, The University of Texas at El Paso, master thesis, $139 \mathrm{p}$.

Gray, H.J., Mahan, S.A., 2015, Variables and potential models for the bleaching of luminescence signals in fluvial environments:
Quaternary International, 362, 42-49.

Gray, H.J., Mahan, S.A., Nelson, M.S., Rittenour, T.M., 2015, Guide to luminescence dating techniques and their application for paleoseismic research in Western States Seismic Policy Council: Basin and Range Province Seismic Hazards Summit III, Utah Geological Survey Miscellaneous Publication, Proceedings Volume, 15-5, variously paginated DVD.

Gustavson, T.C., 1991, Arid basin depositional systems and palaeosols: Fort Hancock and Camp Rice Formations (Pliocene-Pleistocene), Hueco Bolson, west Texas and adjacent México: Texas, U.S.A, Texas Bureau of Economic Geology Report of Investigations, 198, 49 p.

Hall, S.A., Goble, R.J., 2012, Berino Paleosol, Late Pleistocene argillic soil development on the Mescalero Sand Sheet in New México: Nebraska, University of Nebraska, Lincoln Papers in the Earth and Atmospheric Sciences, paper 325; http://digitalcommons.unl.edu/ geosciencefacpub/325.

Hall, S.A., Goble, R.J., Raymond, G.R., 2008, OSL ages of upper Quaternary aeolian sand and paleosols, northwest Albuquerque Basin, New Mexico: New México Geology, 30, 39-49.

Harvey, A.M., Wigand, P.E., Wells, S.G., 1999, Pleistocene to Holocene climatic transition: contrasts between the margins of pluvial Lakes Lahontan and Mojave, Nevada and California, USA: Catena, 36, 255-281

Hawley, J.W., Kottlowsky, F.E., 1969, Quaternary geology of the southcentral New México border region: New Mexico Bureau of Mines and Mineral Resources, Circular 104, 89-115.

Hawley, J.W., Bachman, G.O., Manley, K., 1976, Quaternary stratigraphy in the Basin and Range and Great Plains provinces, New México and western Texas, in Hawley, J.W., Kottlowski, F.E., Seager, W.R., King, W.E., Strain, W.S., LeMone, D.V. (eds.), The Santa Fe Group in the south-central New México border region: Border stratigraphy symposium, New México Bureau of Mines and Mineral Resources, Circular 104, 52-76.

Huntley, D.J., Johnson, H.P, 1976, Thermoluminescence as a Potential Means of Dating Siliceous Ocean Sediments: Canadian Journal of Earth Science 13, 593-596.

Huntley, D.J., Godfrey-Smith, D.I., Thewalt, M.L.W., 1985, Optical Dating of Sediments: Nature 313, 105-107.

Landais, A., Barnola, J.M., Masson-Delmotte, V., Jouzel, J., Chappellaz, J., Caillon, N., Huber, C., Leuenberger, M, Johnsen, S.J., 2004, A continuous record of temperature evolution over a sequence of Dansgaard-Oeschger events during Marine Isotopic Stage 4 (76 to 62 kyr BP): Geophysical Research Letters, 31, L22211.

Mack, G.H., Leeder, M.R., 1998, Channel shifting of the Río Grande, southern Río Grande rift: implications for alluvial stratigraphic models: Sedimentary Geology, 117, 207-219.

Mack, G.H., Seager, W.R., 1990, Tectonic control on facies distribution of the Camp Rice and Palomas Formations (Plio-Pleistocene) in the southern Río Grande rift: Geological Society of America Bulletin, $102,45-53$.

Mack, G.H., Seager, W.R., 1995, Transfer zones in the southern Río Grande rift: Journal of the Geological Society of London, 152, 551-560.

Mack, G.H., Seager, W.R., Leeder, M.R., Arlucea-Perrez, M., Salyards, L.S., 2006, Pliocene and Quaternary history of the Rio Grande, the axial river of the southern Rio Grande rift, New Mexico, USA: Earth Science Reviews, 79, 141-162.

Magaña, V.O., Conde, C., 2000, Climate and freshwater resources in northern Mexico Sonora, a case study: Environmental Monitoring and Assessment, 61, 167-185.

Mahan, S.A., Miller, D.M., Menges, C.M., Yount, J.C., 2007, Late Quaternary stratigraphy and luminescence geochronology of the northeastern Mojave Desert: Quaternary International, 166, 61-78.

Mahan, S.A., Donlan, R.A., Kardos, B., 2015, Luminescence dating of anthropogenic features of the San Luis Valley, Colorado: from stone huts to stone walls: Quaternary International, 362, 50-62.

McDonald, E.V., McFadden, L.D., Wells, S.G., 2003, Regional response of alluvial fans to the Pleistocene-Holocene climatic transition, Mojave Desert, California: Geological Society of America Special Paper 368, 189-205. 
Miller, D.M., Schmidt, K.M., Mahan, S.A., McGeehin, J.P., Owen, L.A., Barron, J.A., Lehmkuhl, F., Lohrer, R., 2010, Holocene landscape response to seasonality of storms in the Mojave Desert: Quaternary International, 215, 45-61.

Muhs, D.R., 2013, The geologic records of dust in the Quaternary: Aeolian Research, 9, 3-48.

Nelson, M.S., Gray, H.J., Johnson, J.A., Rittenour, T.M., Feathers, J.K., Mahan, S.A., 2015, User guide for luminescence sampling in archaeological and geological contexts: Advances in Archaeological Practice, 3, 166-177.

Nodeland, S., 1977, Cenozoic Tectonic of Cretaceous rocks in the Northeast Sierra de Juárez, Chihuahua, México: El Paso, Texas, The University of Texas at El Paso (UTEP), master thesis, $79 \mathrm{p}$.

Ortega-Ramírez, J., Maillol, J.M., Bandy, W., Valiente-Banuet, A., UrrutiaFucugauchi, J., Mortera-Gutiérrez, C.A., Medina-Sánchez, J., Chacón-Cruz, G. J., 2004, Late Quaternary evolution of alluvial fans in the Playa El Fresnal region, northern Chihuahua desert, Mexico: Palaeoclimatic Implications: Geofísíca Internacional, 43, 445-466.

Owen, L.A., Clemmens, S.J., Finkel, R.C., Gray, H., 2014, Late Quaternary alluvial fans at the eastern end of the San Bernardino Mountains, Southern California: Quaternary Science Reviews, 87, 114-134.

Pavia, E.G., Graef, F., Reyes, J., 2006, PDO-ENSO effects in the climate of Mexico: Journal of Climate, 19, 6433-6438.

Personius, S.F., Mahan, S.A., 2000, Paleoearthquakes recurrence on the East Paradise fault zone Metropolitan Albuquerque, New Mexico: Bulletin of the Seismological Society of America, 90, 357-369.

Personius, S.F., Mahan, S.A., 2003, Paleoearthquakes and aeoliandominated fault sedimentation along the Hubble Spring fault zone near Albuquerque, New Mexico: Bulletin of the Seismological Society of America, 93, 1355-1369.
Prescott, J.R. Hutton, J.T., 1994, Cosmic ray contributions to dose rates for luminescence and ESR dating: large depths and long-term time variations: Radiation Measurements, 23, 497-500.

Rhodes, E.J., 2011, Optically stimulated luminescence dating of sediments over the past 200,000 years: Annual Review of Earth and Planetary Sciences, 39, 461-488.

Strain, W.S., 1966, Blancan mammalian fauna and Pleistocene formations, Hudspeth County, Texas: Texas, U.S.A., Texas Memorial Museum Bulletin, 10, $55 \mathrm{p}$.

Vanderhill, J.B., 1986, Lithostratigraphy, vertebrate paleontology, and magnetostratigraphy of Plio-Pleistocene sediments in the Mesilla Basin, New Mexico: Austin, U.S.A, University of Texas, PhD dissertation, $305 \mathrm{p}$.

Wacker, H., 1972, The stratigraphy and structure of Cretaceous rocks in north-central Sierra de Juárez Chihuahua, Mexico: El Paso, Texas, The University of Texas at El Paso (UTEP), master thesis, 82p.

Wintle, A.G., Huntley, D.J., 1979, Thermoluminescence Dating of Ocean Sediments: Council of Europe PACT Journal, 3, 374-380.

Manuscript received: March 12, 2015

Corrected manuscript received: June 10, 2015

Manuscript accepted: June 12, 2015

\section{Supplemental Figures and Tables for:}

\section{Quaternary alluvial fans of Ciudad Juárez, Chihuahua, northern Mexico: OSL ages and implications for climatic history of the region}

Table S.1. Shows high precision gamma spectrometry (Ge detector) data used to obtain the elemental concentrations used to calculate a dose rate.

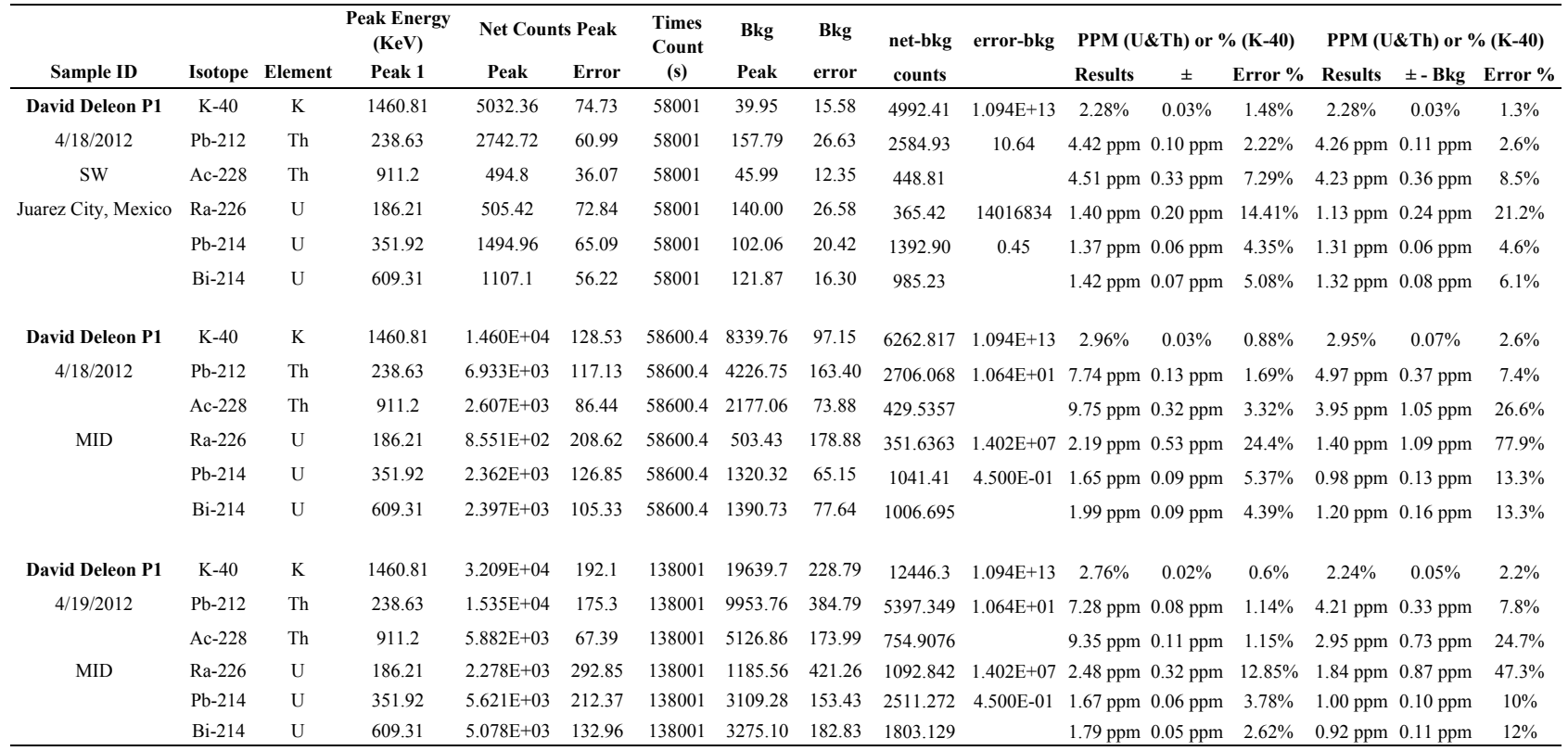


Table S.2. Shows calculation parameters that go into a dose rate. The total dose is shown as Dose ${ }_{\mathrm{R}}$ and each element contribution is shown to the right. The water content can be adjusted and the field moisture, fixed moisture (at $15 \%$ of full saturation or 55 total water), and full saturation is shown.

Ciudad Juarez, eolian sand in alluvial fans-David DeLeon

Dose Rates for sand-grain HF etched, quartz samples

\begin{tabular}{lcccccccccccc}
\hline Sample ID & $\mathrm{K}(\%)$ & $\mathrm{U}(\mathrm{ppm})$ & $\mathrm{Th}(\mathrm{ppm})$ & $\begin{array}{c}\text { Elevation } \\
(\mathrm{m})\end{array}$ & $\begin{array}{c}\text { Depth } \\
(\mathrm{cm})\end{array}$ & $\begin{array}{c}\mathrm{H}_{2} \mathrm{O} \\
(\%)\end{array}$ & Dose $_{\mathrm{R}}$ & $\mathrm{D}_{\mathrm{R}}$ for K & $\mathrm{D}_{\mathrm{R}}$ for $\mathrm{U}$ & $\mathrm{D}_{\mathrm{R}}$ for Th & $\begin{array}{c}\mathrm{D}_{\mathrm{R}} \text { for } \mathrm{Rb} \mathrm{D}_{\mathrm{R}} \text { for cosm } \\
\text { ray }\end{array}$ \\
\hline DeLeonP1 & 2.28 & 1.32 & 4.25 & 1252 & 135 & 1 & 3.138 & 2.2232 & 0.3200 & 0.3239 & 0.0450 & 0.2262 \\
DeLeonP1 & 2.28 & 1.32 & 4.25 & 1252 & 135 & $\mathbf{5}$ & $\mathbf{3 . 0 0 5}$ & 2.1207 & 0.3055 & 0.3095 & 0.0429 & 0.2262 \\
DeLeonP1 & 2.28 & 1.32 & 4.25 & 1252 & 135 & 32 & 2.348 & 1.6175 & 0.2340 & 0.2380 & 0.0326 & 0.2262 \\
DeLeonP2 & 2.65 & 1.09 & 4.97 & 1201 & 555 & 1 & 3.411 & 2.5839 & 0.2642 & 0.3787 & 0.0523 & 0.1319 \\
DeLeonP2 & 2.65 & 1.09 & 4.97 & 1201 & 555 & $\mathbf{5}$ & $\mathbf{3 . 2 6 1}$ & 2.4648 & 0.2523 & 0.3619 & 0.0499 & 0.1319 \\
DeLeonP2 & 2.65 & 1.09 & 4.97 & 1201 & 555 & 32 & 2.521 & 1.8800 & 0.1933 & 0.2784 & 0.0379 & 0.1319 \\
& & & & & & & & & & & \\
DeLeonP3 & 2.24 & 0.96 & 4.21 & 1241 & 455 & 1 & 2.932 & 2.1842 & 0.2327 & 0.3208 & 0.0442 & 0.1498 \\
DeLeonP3 & 2.24 & 0.96 & 4.21 & 1241 & 455 & $\mathbf{5}$ & $\mathbf{2 . 8 0 4}$ & 2.0835 & 0.2222 & 0.3065 & 0.0422 & 0.1498 \\
DeLeonP3 & 2.24 & 0.96 & 4.21 & 1241 & 455 & 32 & 2.125 & 1.5483 & 0.1659 & 0.2299 & 0.0312 & 0.1498 \\
\hline
\end{tabular}

Table S.3. Luminescence parameters used in preparation and analyses of samples for quartz OSL.

\begin{tabular}{ll}
\hline Measurement parameters: & \\
\hline Machine & Automated Risø TL/luminescence-DA-15 \\
Mineral; grain size: & quartz: $250-180 \mu \mathrm{m}$ \\
Stimulation source: & blue LED diodes, emission centered on $470 \mathrm{~nm}$ \\
Power delivered to aliquot: & $9 \mathrm{~mW} / \mathrm{cm}^{2}(90 \%$ power $)$ \\
Duration of stimulation: & 40 seconds \\
Final signal level: & $3 \%$ of initial \\
Photomultiplier: & Thorn-EMI $9235 \mathrm{Q}$ \\
Aliquot temperature: & $125{ }^{\circ} \mathrm{C}$ \\
Detection filters: & two Hoya U340 filters \\
Normalization: & none \\
Preheat: & $240{ }^{\circ} \mathrm{C}$ (samples $<5$ ka) for 10 secs \\
Delay before measurement: & 120 sec \\
\hline Equivalent dose evaluation: & single aliquot regeneration $($ Murray and Wintle, 2000, 2003 ) \\
Background evaluation: & black body counts $<23$ ct/sec, BG counts $<25$ ct/sec \\
Alpha effectiveness: & n/a \\
Dose-rate evaluation: & high-resolution gamma spectrometry \\
Dose rate range: & $2.80-3.26$ Gy/ka (Grays per thousand years) moderate range \\
Water content: & $15 \%$ of full saturation \\
Cosmic-ray contribution: & $5-8 \%$ of total dose rate, independent of sampling site \\
\hline & \\
\hline
\end{tabular}


Table S.3. Luminescence parameters used in preparation and analyses of samples for quartz OSL.

1. Preheat $\left(240^{\circ} \mathrm{C}\right)$ for 10 seconds (preheat range is specific to Cuidad Juarez sample

2. OSL stimulation with blue light $(470 \mathrm{~nm})$ at $125^{\circ} \mathrm{C}$ for 40 seconds $\left(\mathrm{L}_{\mathrm{n}}\right)$

3. Test dose beta irradiation

4. Cut heat (same temp as preheat) for $0 \mathrm{sec}$

5. OSL stimulation with blue light $(470 \mathrm{~nm})$ at $125^{\circ} \mathrm{C}$ for 40 seconds $\left(T_{n}\right)$

6 . Beta irradiation of regeneration dose

7. Preheat $\left(240^{\circ} \mathrm{C}\right)$ for 10 seconds

8. OSL stimulation with blue light $(470 \mathrm{~nm})$ at $125^{\circ} \mathrm{C}$ for 40 seconds $\left(\mathrm{L}_{\mathrm{x}}\right)$

9. Test dose beta irradiation

10. Cut heat (same temp as preheat) for $0 \mathrm{sec}$

11. OSL stimulation with blue light $(470 \mathrm{~nm})$ at $125^{\circ} \mathrm{C}$ for 40 seconds $\left(\mathrm{T}_{\mathrm{x}}\right)$

12. Repeat Steps 6-11 with further regeneration doses

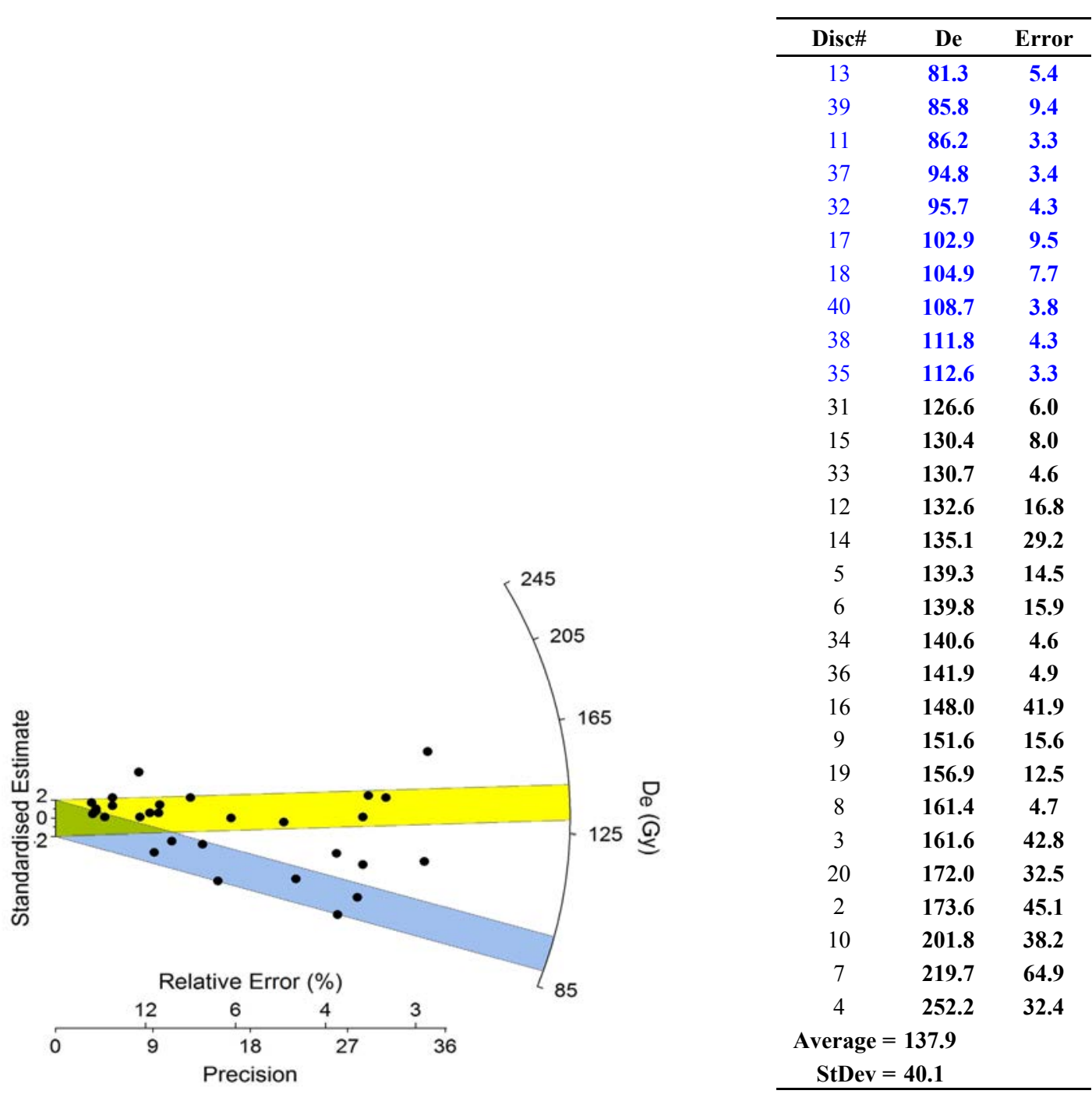

Figure S.1. P1 radial plot and data used to construct the radial plot (above). The first population of equivalent doses is highlighted with a blue bar at 93.2 Gy, $\mathrm{n}=10$ (30) and a possible second population in the yellow bar at $135 \mathrm{~Gy} \mathrm{n}=16$ (30). 5 (30) aliquots (or discs) are shown as outliers above the yellow and blue bars but are included to show that they essentially do not contribute to the standardized estimate, as calculated using the radial plot program, even though they passed protocol tests. One aliquot did not pass the tests and was not included in any calculations. Degree of dispersion is measured by the standard deviation for all of the aliquots. For this sample, the standard deviation is $40.1 \mathrm{~Gy}$ or about $29 \%$ dispersion. > $30 \%$ dispersion is a major indicator of partial bleaching or, in rare cases, microdosimetry variances. 


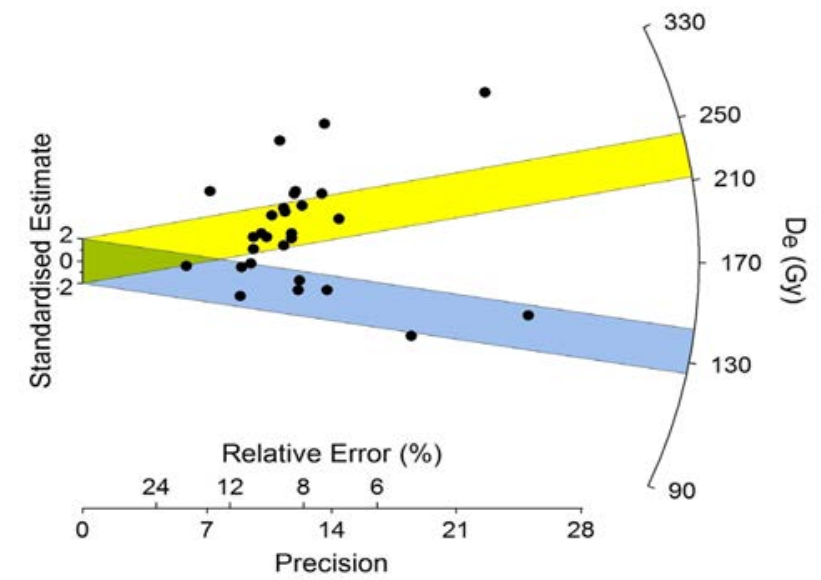

\begin{tabular}{|c|c|c|}
\hline Disc\# & De & Error \\
\hline 33 & 118.1 & 6.4 \\
\hline 37 & 118.8 & 13.4 \\
\hline 48 & 137.1 & 11.3 \\
\hline 27 & 139.9 & 5.6 \\
\hline 29 & 139.9 & 10.2 \\
\hline 26 & 147.2 & 12.1 \\
\hline 39 & 157.1 & 29.7 \\
\hline 24 & 159.7 & 17.8 \\
\hline 46 & 165.9 & 17.5 \\
\hline 40 & 191.7 & 20.0 \\
\hline 47 & 194.0 & 17.2 \\
\hline 45 & 203.1 & 17.3 \\
\hline 32 & 209.5 & 20.3 \\
\hline 43 & 211.0 & 17.9 \\
\hline 34 & 213.8 & 22.3 \\
\hline 21 & 219.4 & 21.8 \\
\hline 25 & 220.8 & 15.3 \\
\hline 31 & 251.1 & 23.6 \\
\hline 38 & 251.8 & 22.1 \\
\hline 44 & 254.1 & 20.6 \\
\hline 30 & 260.7 & 23.1 \\
\hline 41 & 267.5 & 19.9 \\
\hline 36 & 282.5 & 23.8 \\
\hline 42 & 287.8 & 24.1 \\
\hline 23 & 332.3 & 14.7 \\
\hline 35 & 411.8 & 57.6 \\
\hline 22 & 421.4 & 31.0 \\
\hline 28 & 448.1 & 40.4 \\
\hline \multicolumn{3}{|c|}{ Average $=229.1$} \\
\hline \multicolumn{3}{|c|}{ StDev $=\mathbf{8 8 . 9}$} \\
\hline
\end{tabular}

Figure S.2. P2 radial plot and data used to construct the radial plot (above). The first population of equivalent doses is highlighted with a blue bar at 134 Gy, $\mathrm{n}=9$ (30) and a possible second population in the yellow bar at $225 \mathrm{~Gy} n=14$ (30). 2 (30) were not used to construct the radial plot because they did not pass protocol tests during measurement of the equivalent dose. 7 (30) aliquots (or discs) are shown as outliers above the yellow and blue bars but are included to show that they essentially do not contribute to the standardized estimate, as calculated using the radial plot program, even though they passed protocol tests. Degree of dispersion is measured by the standard deviation for all of the aliquots. For this sample, the standard deviation is 88.9 Gy or about $39 \%$ dispersion. $>30 \%$ dispersion is a major indicator of partial bleaching or, in rare cases, microdosimetry variances.

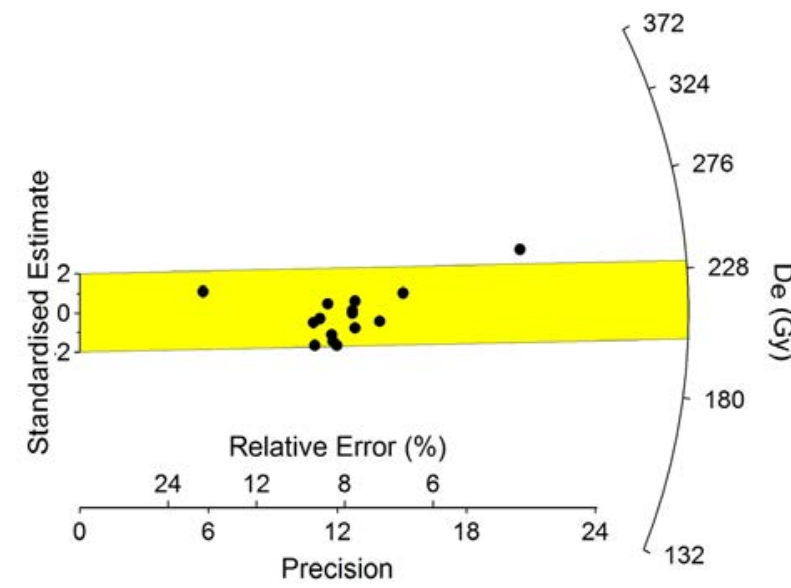

\begin{tabular}{ccc}
\hline Disc\# & De & Error \\
\hline 44 & $\mathbf{1 8 0 . 5}$ & $\mathbf{1 6 . 5}$ \\
47 & $\mathbf{1 8 3 . 0}$ & $\mathbf{1 5 . 3}$ \\
4 & $\mathbf{1 8 5 . 6}$ & $\mathbf{1 5 . 7}$ \\
2 & $\mathbf{1 9 0 . 2}$ & $\mathbf{1 6 . 2}$ \\
1 & $\mathbf{1 9 7 . 5}$ & $\mathbf{1 5 . 4}$ \\
6 & $\mathbf{2 0 0 . 1}$ & $\mathbf{1 8 . 4}$ \\
42 & $\mathbf{2 0 3 . 8}$ & $\mathbf{1 4 . 6}$ \\
46 & $\mathbf{2 0 4 . 3}$ & $\mathbf{1 8 . 2}$ \\
3 & $\mathbf{2 0 9 . 7}$ & $\mathbf{1 6 . 5}$ \\
7 & $\mathbf{2 1 3 . 4}$ & $\mathbf{1 6 . 8}$ \\
43 & $\mathbf{2 1 9 . 3}$ & $\mathbf{1 9 . 0}$ \\
5 & $\mathbf{2 2 0 . 9}$ & $\mathbf{1 7 . 2}$ \\
45 & $\mathbf{2 2 5 . 7}$ & $\mathbf{1 5 . 0}$ \\
48 & $\mathbf{2 4 5 . 7}$ & $\mathbf{1 2 . 0}$ \\
41 & $\mathbf{2 5 4 . 4}$ & $\mathbf{4 4 . 2}$ \\
Average $=\mathbf{2 0 8 . 9}$ & \\
StDev $=\mathbf{2 1 . 7}$ &
\end{tabular}

Figure S.3. P3 radial plot and data used to construct the radial plot (above). The only population of equivalent doses is highlighted with a yellow bar at $208 \mathrm{~Gy}, \mathrm{n}=14$ (15). 1 (15) aliquots (or discs) is shown as an outlier above the yellow bar but is included in the data to show that it essentially did not contribute to the standardized estimate, as calculated using the radial plot program, even though it passed protocol tests. Degree of dispersion is measured by the standard deviation for all of the aliquots. For this sample, the standard deviation is $21.7 \mathrm{~Gy}$ or about $10 \%$ dispersion. $>30 \%$ dispersion is a major indicator of partial bleaching or, in rare cases, microdosimetry variances. 

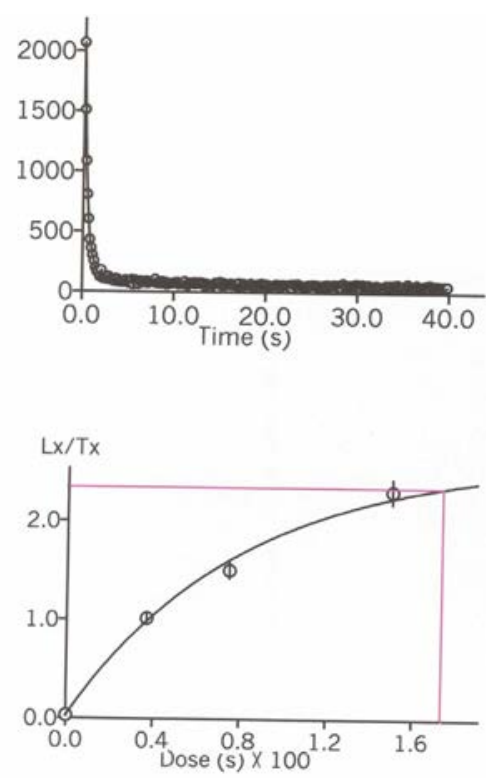

Figure S.4A. An OSL decay curve for P1 showing the quartz signal as measured with blue-light wavelength emitting diodes. The $\mathbf{x}$-axis is time of measurement in seconds (s) and the $\mathbf{y}$-axis is photon counts/second over the course of the 40 second measurement period (here a little over 2000 photons/sec at the start of the LED's stimulation). A sharp decay is seen after 1 to 2 seconds of stimulation indicating access from a fast component of OSL. The OSL equivalent dose data is taken from the initial part of the first $0.5 \mathrm{sec}$. and the background adjustment is taken from the last second of the 40 second measurement. S.4B. P1 growth curve, with the natural (red lines) plotted on the $\mathrm{Lx} / \mathrm{Tx}$ axis above 2.0. The $\mathbf{x}$-axis is the equivalent dose measured in Grays (source calibration is $0.087 \mathrm{~Gy} / \mathrm{sec}$ and shown circles are obtained at $37 \mathrm{~Gy}, 75 \mathrm{~Gy}, 150 \mathrm{~Gy}$ ). The natural hits the linear line at about $174 \mathrm{~Gy}$ for this particular aliquot (Disc \#2). The bleach (zero) is shown at the junction of the axes. The $\mathbf{y}$-axis shows the luminescence response over the test dose response ( $\mathrm{Lx} / \mathrm{Tx}$ or unitless normalized OSL sensitivity measurements). Regeneration proceeded "optimally", with a recycle within $3 \%$ of the first measurement (two clustered circles close to the $1.0 \mathrm{x}$-axis mark).
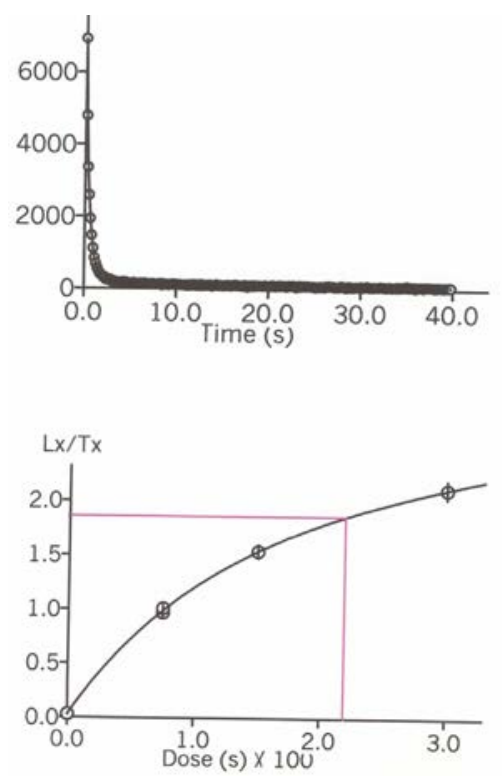

Figure S.5A. An OSL decay curve for $\mathbf{P} 2$ showing the quartz signal as measured with blue-light wavelength emitting diodes. The $\mathbf{x}$-axis is time of measurement in seconds (s) and the $\mathbf{y}$-axis is photon counts/second over the course of the 40 second measurement period (here a little over 6000 photons/sec at the start of the LED's stimulation). S.5B. P2 growth curve, with the natural (red lines) plotted on the Lx/Tx axis between 1.5 and 2.0. The $\mathbf{x}$-axis is the equivalent dose measured in Grays (source calibration is $0.087 \mathrm{~Gy} / \mathrm{sec}$ and shown circles are obtained at $75 \mathrm{~Gy}, 150 \mathrm{~Gy}, 300 \mathrm{~Gy}$ ). The natural hits the linear line at about 219 Gy for this particular aliquot (Disc \#21). The bleach (zero) is shown at the junction of the axes. The $\mathbf{y}$-axis shows the luminescence response over the test dose response (Lx/ Tx or unitless normalized OSL sensitivity measurements). Regeneration proceeded "optimally", with a recycle within $4 \%$ of the first measurement (two clustered circles close to the $1.0 \mathrm{x}$-axis mark). 

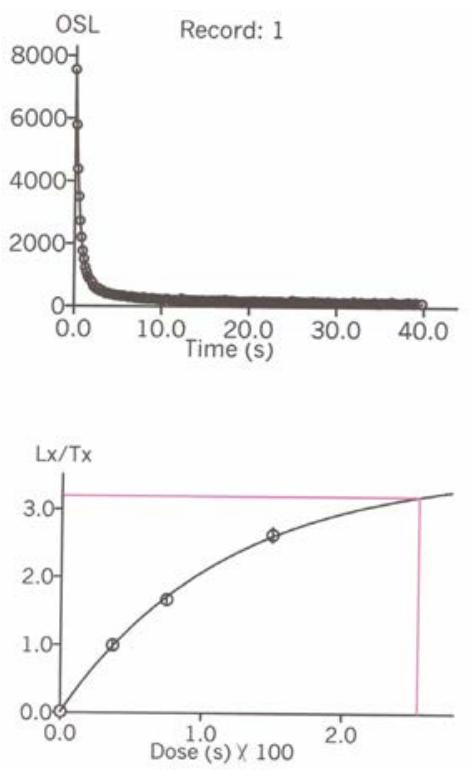

Figure S.6A. An OSL decay curve for $\mathbf{P 3}$ showing the quartz signal as measured with blue-light wavelength emitting diodes. The $\mathbf{x}$-axis is time of measurement in seconds (s) and the $\mathbf{y}$-axis is photon counts/second over the course of the 40 second measurement period (here a little over 8000 photons/sec at the start of the LED's stimulation). S.6B. P3 growth curve, with the natural (red lines) plotted on the Lx/Tx axis above 3.0. The $\mathbf{x}$-axis is the equivalent dose measured in Grays (source calibration is $0.087 \mathrm{~Gy} / \mathrm{sec}$ and shown circles are obtained at $37 \mathrm{~Gy}, 75 \mathrm{~Gy}, 150 \mathrm{~Gy}$ ). The natural hits the linear line at about $255 \mathrm{~Gy}$ for this particular aliquot (Disc \#41). The bleach (zero) is shown at the junction of the axes. The $\mathbf{y}$-axis shows the luminescence response over the test dose response (Lx/ Tx or unitless normalized OSL sensitivity measurements). Regeneration proceeded "optimally", with a recycle within $4 \%$ of the first measurement (two clustered circles close to the $1.0 \mathrm{x}$-axis mark). 